\title{
Revisiting the appropriation of space in metropolitan river corridors.
}

\author{
Published as Benages-Albert, M., Di Masso, A., Porcel, S., Pol, E., \& Vall-Casas, P. \\ (2015). Revisiting the appropriation of space in metropolitan river corridors. Journal \\ of Environmental Psychology, 42, 1-15.
}

\begin{abstract}
This article reintroduces the concept of 'appropriation of space' into current theoretical debates and empirical approaches in environmental psychology. We present an analysis of a case study conducted in a Barcelona metropolitan river corridor, aimed at exploring how the development of people-place bonds can foster pro-environmental behaviours in a natural open space.

The multi-method qualitative analysis based on participant observation, documentary research and interviews with 57 inhabitants reveals a long-term process of appropriation of the riverside environment that typically results in a sense of responsibility of the subject towards it. The article specifically shows that the time factor is crucial in the explanation of the process of appropriation, and that future longitudinal studies in this and other cases will be required to assess more accurately its importance. Finally, we stress the benefits of taking proper advantage of citizens' cumulative awareness of the management of river corridors.
\end{abstract}

\section{KEYWORDS}

Appropriation of space; temporal dimension; Barcelona river corridor; environmental restoration; multi-method 


\section{INTRODUCTION}

Peri-urban open spaces are perceived as an essential component of quality of life in densely-populated areas (Harnik, 2000). These places allow people to pursue activities in contact with nature, with beneficial effects on their health and psychological wellbeing that have started to be explored in recent decades (Kaplan, Kaplan \& Ryan, 1998; Gifford, 2007). Furthermore, people establish emotional bonds with these places which become a powerful force in their preservation and improvement (Ryan, 2000, 2005). Specifically, the appreciation of and commitment to natural peri-urban spaces can encourage responsible environmental behaviour patterns (Hines, Hungerford \& Tomera, 1987; Grob, 1995; Jiménez, 1997; Scannell \& Gifford, 2010b), catalyse a significant level of voluntary work and generate private financial resources for their maintenance (Platt, 2006), ultimately making an important contribution to their sustainability.

From this perspective, metropolitan rivers deserve special consideration due to their growing social use after decades of intensive degradation and neglect, something that is closely associated with urban pressure and the risk of flooding. Contact with nature, engaging in sport, celebrating events, daily strolls and cultivating the soil for recreational purposes all explain, to a large extent, the daily use of river areas that has become progressively consolidated from the 1980s in developed countries around the world (Novotny, Ahern \& Brown, 2010; Warner, Van Buuren \& Edelenbos, 2013). Actually, river corridors have become significant collective places and they play a crucial role in the legibility of urban regions (Lynch, 1960, 1984). In this sense, the new culture of water and landscape, specified in the European Water Framework Directive (European Council, 2000a) and the European Landscape Convention (European Council, 2000b), confirms the importance of these watercourses for the wellbeing of metropolitan communities, and 
underlines the need for collective involvement in the sustainable management of the water cycle and the riverside landscape (Mc Harg, 1969). In accordance with the evident importance of this approach within a European context, over the last few years public administrations have carried out significant work with a view to the physical and social recovery of river corridors (e.g. Benages-Albert \& Vall-Casas, 2014), but there is still a long way to go to achieve generalized responsible pro-environmental behaviour.

Within the academic domain, environmental-psychological research has provided powerful conceptual tools to account for how people establish bonds with their life-spaces, and how such people-place bonds may be beneficial to foster pro-environmental commitments and protection-oriented behaviours. Among these concepts, appropriation of space (Graumann, 1976; Korosec-Serfaty, 1976; Pol 1996; Vidal \& Pol, 2005 ${ }^{1}$ ) is particularly suited to broach the psychological investments towards places. On the one hand, it specifically highlights the temporal dimension in the construction of people-place bonds, articulating both place identification and emotional aspects as evolving experiences. For instance, it allows framing within the life-cycle the strong sense of "insideness" (Rowles, 1983) that the elderly may feel towards the town they have lived in since they were born. Or it allows the exploration of inter-generational continuity through symbolic relationships with certain home-spaces where things are stored and re-valued over time (see Korosec-Serfaty, 1984, on attics and cellars as time-repositories). On the other hand, it explicitly brings into sharper focus the territorial processes (among them sociospatial conflicts) shaping or undermining experiences of place attachment.

However, despite the analytical specificities and integrative potential of space-

\footnotetext{
${ }^{1}$ The concept of the appropriation of space has been extensively used, outside psychology, by urban sociologists and political geographers drawing on the Marxist philosopher Henri Lefebvre (Lefebvre, 1974; Mitchell, 1995).
} 
appropriation, this concept has progressively been replaced by mostly individualistic and atomistic approaches, to the point where it is currently somewhat overlooked. Other similar concepts, especially place-attachment (Altman \& Low, 1992; Hidalgo, 1998; Giuliani, 2003), place identity (Proshansky, Fabian \& Kaminoff, 1983), and sense of place (Hay, 1988; Gustafson, 2001), amongst others, have experienced better fortune when it comes to explaining the basis of the phenomenon of what it is that links people with spaces. It is likely that linguistic connotations have also had an influence, the term 'appropriation of space' being clear in French and other Latin-based languages (Spanish, Italian and Catalan), yet confusing in its English meaning (Pol, 2002). On this point, we think it is worth recovering the term 'appropriation of space' (Pol, 1996), given its potential to reintegrate within one same temporal process place-related psychological experiences such as place identity, place attachment or place preference, rather than treating such constructs as neatly separated entities somehow interrelated in a part-whole relationship (e.g. Pretty, Chipuer \& Bramston, 2003; Kyle, Graefe \& Manning, 2005). The concept of appropriation allows the redefinition of such constructs as different experiential moments within one same ongoing process of territorial and symbolic relationship with places.

Consequently, this article is a deliberate attempt to reintroduce appropriation of space into current theoretical debates and empirical approaches aiming to explain how and why people, as time goes by, actively create and sustain affective and territorial bonds to previously unused or less used environments.

\subsection{The concept of appropriation of space}

The origin of the concept of appropriation of space goes back to the 1960s at the start of what some scholars consider the "second coming" of environmental psychology (Pol, 
1988), with Moles, Rohmer, Fischer and Korosec-Serfaty as the main proponents of one of the perspectives that they called the 'psychology of space'. The main, but not the only, impetus behind the theory of the appropriation of space was due to Korosec-Serfaty, promoter of an international conference held in 1976 that made this concept clear to the scientific community. As far as Korosec-Serfaty was concerned, appropriation of space can be understood as a feeling of possessing and managing a space, irrespective of its legal ownership, for its everyday use or as a means of identification. This conference also highlighted the views of Graumann (1976), who defined appropriation as a way of interiorizing space, and Proshanky (1976), who directly associated appropriation of space with personal identification, probably as an antecedent to developing his subsequent theories about the identity of space (Proshansky, 1978; Proshansky et al, 1983). During the 1980s, however, the concept of appropriation was seldom drawn on to explain how and why people develop transient or long-standing bonds with their life-environments (with some exceptions, see Korosec-Serfaty, 1984), and was narrowly defined as the "act of exercising control over a particular physical setting" (Brower, 1980, p.183), that is, it was generally conceptualised as a subcomponent of a broader process of territoriality (see Brown, 1987; Gifford, 1987).

Years later, the theoretical model known as the dual model of appropriation of space (Pol, 1996; Pol, 2002; Vidal \& Pol, 2005) was proposed as a systematic attempt to theorize how people establish bonds with their life-spaces in a way that integrates both symbolic and material processes shaping the environmental experience. The time variable was underlined in this model as a crucial one, proposing that spatial appropriation unfolds diachronically through the reciprocal feedback between territorial actions and personal/social identifications; both of which are present throughout everybody's life-cycle but with a 
different weighting at each stage. According to this model, individual and collective actions transform and attribute meaning to the space, while symbolic identifications with the transformed space reciprocally activate bonds between people and groups (see Figure 1). Therefore, the duality and interaction of the behavioural (the action of transforming the space) and the symbolic (affective, cognitive and interactive processes) components allows the physical space to be transcended and to connect to other places recreated from the memory and imagination of the subject (Di Masso, Vidal \& Pol, 2008, p.376).

\section{FIGURE 1}

Diagram of the process of the appropriation of space. Adapted from Vidal \& Pol, 2005

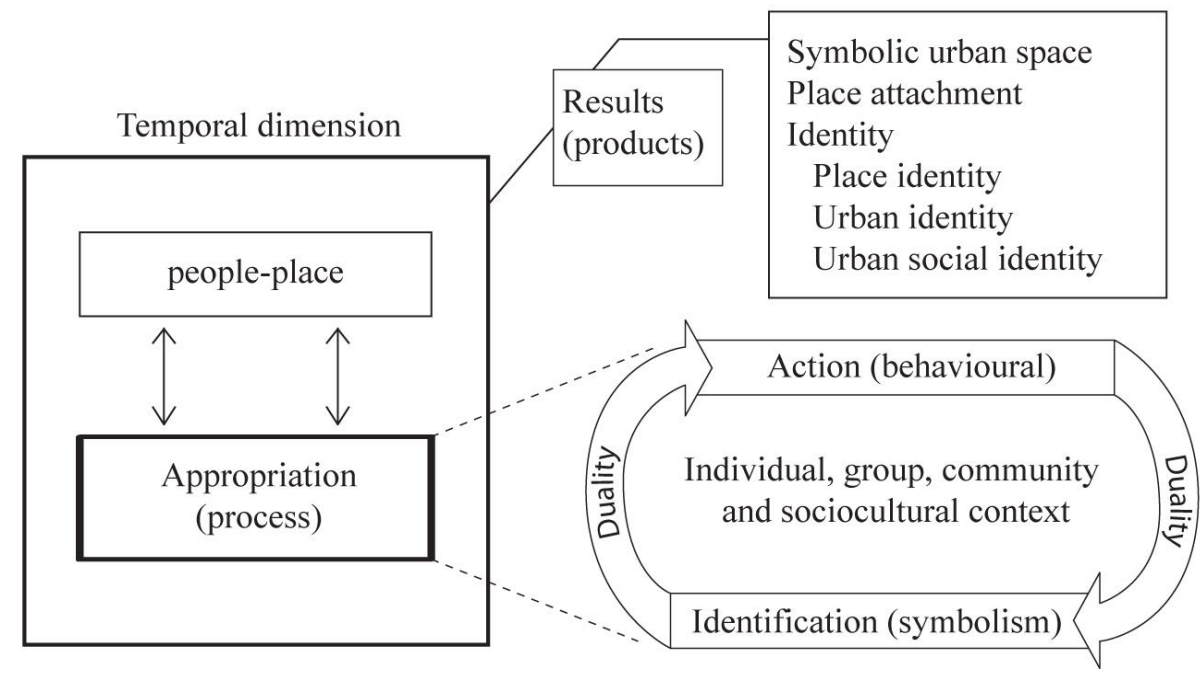

This dual model of appropriation of space has been tested out in dense urban environments. As an example, in a Barcelona neighbourhood immersed in a profound housing remodelling plan, both identification with the place, as well as inhabitants' practices, explained people-place bonds (Vidal, 2002).

Considering both original and more recent contributions, it is possible to distill at least four analytical advantages of the concept of space-appropriation compared to similar environmental-psychological concepts (i.e. place attachment, place dependence, etc.). First 
and most clearly, as we stated earlier, it incorporates the temporal dimension given the attention paid to how people-place bonds evolve across life-cycle stages (Pol, 1996), how time becomes condensed in memories that bind people to places (Korosec-Serfaty, 1984) and how spatial usages transform territorial involvement into place-identification (Vidal \& Pol, 2005). Second, it emphasises the dialectic nature of the bonding process (behavioural and symbolism). Third, it makes the territorial and embodied dimensions of place-bonding clearer. And fourth, it encourages a clearer understanding of the potential conflict provoked by different uses and transformations of space (Di Masso, Dixon \& Pol, 2011; see also Hay, 1998, on conflicts with indigenous people having spiritual bonds with places). To be sure, very few studies have attempted an integrative conceptualisation such as this one (see Scannell and Gifford's (2010a) 'tripartite model of place attachment', and Pinheiro (2013) as suggesting exceptions).

The temporal dimension of people-based bonds, although not neglected (see Altman \& Low, 1992), has been limited to particular environments and psychological experiences (e.g. the home -Werner, Altman \& Oxley, 1985; environmental attitudes -Milfont \& Gouveia, 2006; or memory -Chawla, 1992; Rubinstein \& Parmelee, 1992; Lewicka, 2008). Under the model of space appropriation, time-factors shaping people-place relations can be more detailed, covering life-cycle stages, inter-generational bonds, self-memories, family narratives of the past, cultural representations of the history of a place, and time spent in a space at different scales.

Based on this background, this article aims to test the dual model of space appropriation in peri-urban environments which are in the process of urban regeneration; specifically, the process of people-environment bonding around a river corridor in the metropolitan area of Barcelona was analysed. 


\subsection{Research questions}

As a starting point, the two interrelated questions that guided the research were formulated as follows: Has there been a process of spatial appropriation of the Caldes river by its nearby inhabitants? If this is the case: How do spatial, territorial, affective and identityrelated aspects combine to articulate such experience of appropriation?

To tackle these questions, we start by assuming the importance of analysing how peopleplace bonds can foster pro-environmental commitments and the suitability of reintroducing the concept of the appropriation of space. The aim is to explore what environmentalpsychological conditions regulate the process of appropriation. To do so, the paper is divided into three sections along with the introduction and the conclusions. The first section explains the method and specific procedure for obtaining and processing experiential data. The second section analyses the results obtained with respect to the appropriation process. Finally, the main theoretical and empirical input is discussed as well as opening up a wider discussion on the subject of the progressive responsibility of citizens with respect to river corridors as a regeneration strategy for metropolitan open spaces.

\section{METHOD}

\subsection{Context}

The space chosen for the study was the Caldes river (Barcelona) as a prime example of the changes that the landscape and the perception of river corridors have undergone in the cities of the developed world (Stanton, 2005; Novotny et al, 2010; Warner et al, 2013). During the 1960s and 1970s, the Caldes river suffered from the reiterated impact of unfettered urbanization, pollution, flooding and channelling, especially relevant in the Mediterranean context and characteristic of the transformation of rural land into suburban sprawl. The 
sense of belonging that prevailed during the first half of the $20^{\text {th }}$ century, when the river's contribution to irrigation, energy and raw materials was essential for a still agrarian economy, was replaced by a progressive disconnection. The industrial development, with the subsequent loss of the river's economic significance and its environmental degradation, propitiated the abandonment of the river banks that went on to become marginalized areas (Canyameres, 2004; Panareda, 2009). Yet from the start of the 1980s, the efforts made to improve environmental quality, the prevention of flood risk and the social recovery of the area around the river encouraged responsible pro-environmental behaviour and the emergence of self-organized citizen groups (Gordi, 2005; Benages-Albert \& Vall-Casas, 2014). Currently, the Caldes river plays a strategic role in the physical and social integration of an urban infrastructure of close to 60,000 inhabitants (Torra, Farrero \& Ténez, 2008; Generalitat de Catalunya, 2010).

This example also illustrates the difficult coexistence between the typical economic, social and environmental functions of metropolitan rivers. The Caldes river in particular articulates one of the most emblematic industrial corridors of the metropolitan region of Barcelona, endowed with large river parks that have contributed to the prestige of this productive area (Generalitat de Catalunya, 1987, 1988). Moreover, the river has become the daily backdrop for many riverside residents, who use it for everyday leisure activities, and also for many city dwellers who use the area for cultural and recreational pursuits at the weekend. By the same token, the environmental value of the river, in addition to its economic and social importance (Benages-Albert \& Vall-Casas, 2014), strengthens the interest in this case to address the psycho-environmental determining factors that affect the appropriation of metropolitan rivers in all their complexity. 


\section{FIGURE 2}

Urban settlements and river corridors of the Besòs basin in the Barcelona Metropolitan Region. Source: Authors, adapted from ICC maps.

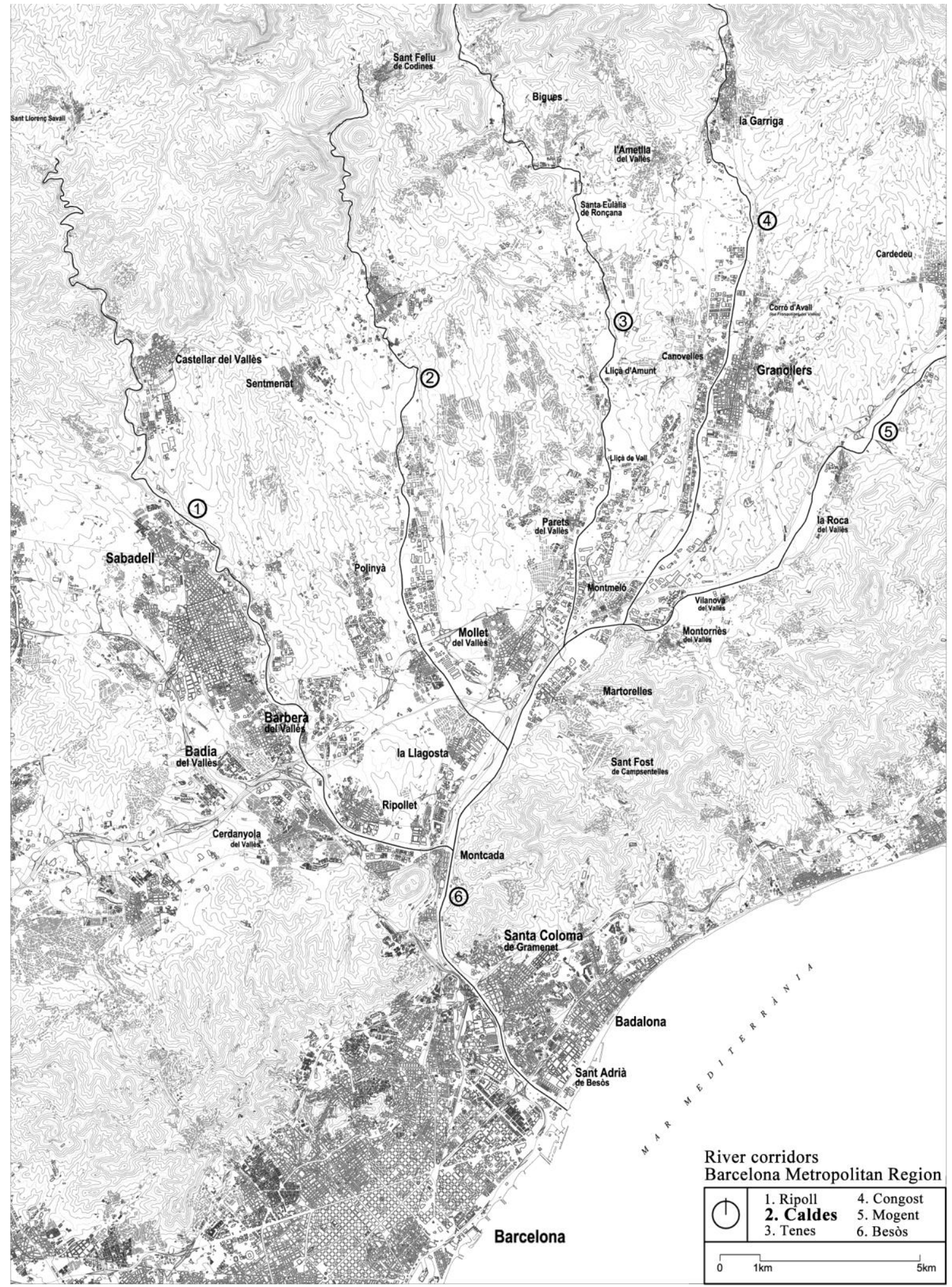


FIGURE 3

Riverside parks around Caldes river. Source: Authors, adapted from Google maps.
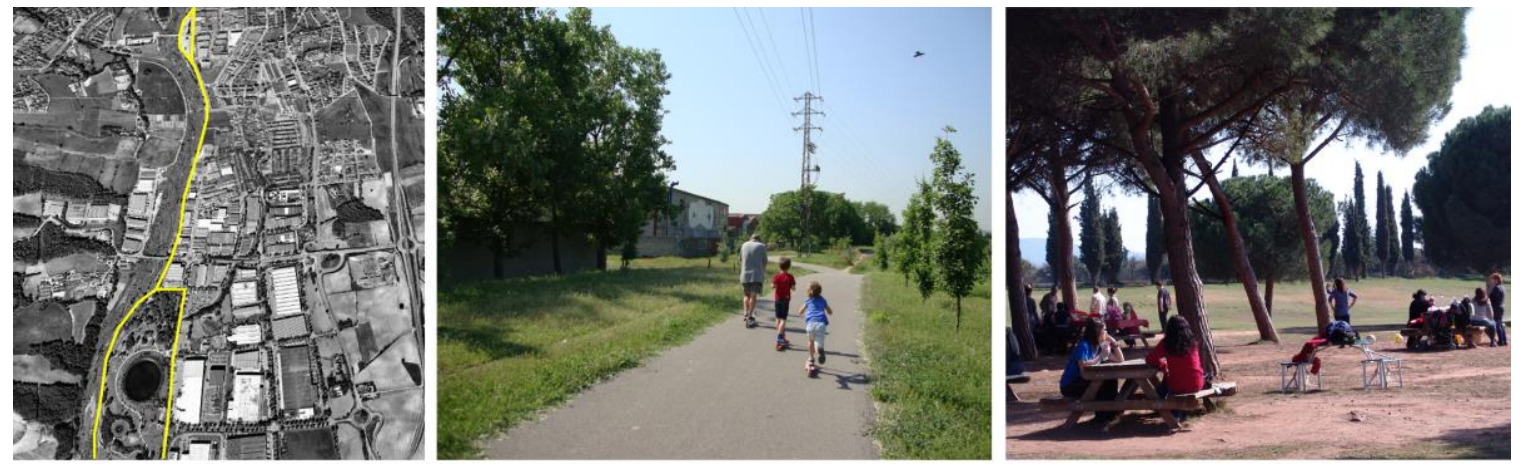

\subsection{Methodological approach}

To achieve the research objectives and capture the interaction mechanisms between the physical setting, social practices, place meanings and experiences, the study adopted a qualitative multi-method approach (Brewer \& Hunter, 2006) based on a naturalistic perspective (Barker \& Wright, 1951; Hammersley \& Atkinson, 1994; Creswell, 1998, 2007), close to phenomenology in several parts of the research process (Relph, 1976; Hyncer, 1985;). On the one hand, qualitative data provide a high level of sensitivity towards subjectivities related to people's perceptions and experiences of their surroundings. On the other hand, the multi-method methodological strategy, based on the complementarity of different types of qualitative methods, offers the chance to explore the phenomenon under study from a much broader perspective, facilitating and increasing comprehension the closer one gets to obtaining the 'full picture'. In addition, the attitude adopted when compiling and analysing data was to show the utmost respect for the relationship between the information gathered and the environment in which the data 
originated or to which it referred, preserving or reinforcing the spatial dimension of the data $^{2}$.

\subsection{Fieldwork}

Fieldwork was undertaken over a period of one-and-a-half years (February 2011 September 2012) and consisted of gathering available documentation - postcards and archive photographs, publications and local press- and the in-house production of information through interviews, observations and photographs. A description of the body of data analysed is given below.

\subsubsection{Participant observation}

During an initial phase from February to July 2011, four exploratory visits were made where observation of the surroundings was combined with some conversations with local residents in order to appreciate the space based on the interaction between the people and spatial components, without decontextualizing it. During this phase, descriptive notes were taken and different categories were established (Alexander, Ishikawa \& Silverstein, 1977) for the spaces and types of activity carried out near the river and, at the same time, key sources were identified for in-depth interviews concerning their connection with the river. In a second phase and running parallel to the in-depth interviews (see section 2.3 .3 on page 13), regular visits were made (a total of 31) over one whole year (August 2011 - September 2012) to the river area to round off the oral information from the interviews with naturalistic observation. During this

\footnotetext{
${ }^{2}$ Some authors have used similar methodological procedures with qualitative data, using the term geoethnography (Matthews, Detmiler \& Burton, 2005) or geo-coding (Verd \& Porcel, 2012).
} 
phase, the ethnographic notes were of a more reflexive nature and were linked to the information arising from the interviews.

\subsubsection{Documentary research}

At the same time as the exploratory visits during the first few months of the fieldwork, documentary research was carried out using local sources from three different municipalities to ascertain the relationship between the local population and the river from a historical perspective. Meanwhile, the local press in each municipality was reviewed to get an impression of the image projected by the local media in recent times. Both lines of documentary research underlined the need to interview inhabitants of various ages in order to obtain a more comprehensive interpretation of the

transformations experienced by the riverside landscape since the beginning of the $20^{\text {th }}$ century. Furthermore, articles published in local newspapers represented key sources for conducting in-depth interviews during the next phase.

\subsubsection{In-depth interviews and walking interviews}

In total, 50 in-depth interviews and 7 walking interviews (Jones, Bunce, Evans, Gibbs \& Ricketts Hein, 2008) were held between August 2011 and September 2012. When it came to selecting the interviewees, in order to obtain a variety of inputs with regard to the use of the territory under study, individuals connected to the river were gathered from a range of sociodemographic profiles covering three municipalities along the river. Additionally, the control variables taken into account for the selection of interviewees were the age of the individuals and the number of years they had lived in 
the municipality ${ }^{3}$, with the aim of observing whether these attributes played an important role in explaining variability with respect to their experiences and bonds with the place. All respondents were approached personally and selected following the snowball sampling technique according to the previous criteria.

Based on an initial estimate of the sample, the importance of the time factor was noted in the inhabitants' narrative, and special attention was given to the time factors shaping the people-place relationships mentioned in the introduction: life-cycle stages ${ }^{4}$, intergenerational bonds, self-memories, family narratives of the past, cultural representations of the history of a place, and time spent in a space at different scales.

TABLE 1

\section{Characterization of interviewees}

\begin{tabular}{|c|c|c|c|c|c|c|c|c|c|c|c|c|c|c|}
\hline \multirow[t]{2}{*}{ Inhab. } & \multicolumn{4}{|c|}{ Age stage } & \multicolumn{3}{|c|}{ Length of residence } & \multicolumn{4}{|c|}{ Years of relation with the river } & \multicolumn{3}{|c|}{ Generation } \\
\hline & $15-29$ & $30-49$ & $50-69$ & $70+$ & $<10$ & $10-25$ & $25+$ & $<5$ & 5- 9 & $10-24$ & $25+$ & 1 st & $2 \mathrm{nd}$ & $3 \mathrm{rd}$ \\
\hline 57 & 7 & 17 & 22 & 11 & 1 & $\begin{array}{c}14 \\
5 \text { born }\end{array}$ & $\begin{array}{c}42 \\
\text { 34born }\end{array}$ & 13 & 16 & 16 & 12 & 18 & 28 & 11 \\
\hline
\end{tabular}

"n born" indicates the number of inhabitants who are born in the area over the total.

In-depth interviews were conducted based on the same script with open-ended questions based around two main subjects: knowledge of the river and its surroundings, and the relationship of the interviewees with the river space based on memories, the current situation and expectations for the future.

The walking interviews were undertaken following the same script but proved to be particularly effective for identifying the most territorial aspects of people's place attachment, that is to say, those aspects of the person-place bond that develop as people

\footnotetext{
${ }^{3}$ The years of residence in the riverside municipalities were classified in three groups, according to the data identified in section 2.1. Context: (1) less than 10 years (2003-2012) - the river as a river park for recreational use, (2) between 10 and 25 years (1988-2002) - the environmental recovery of the river, (3) over 25 years (before 1988) - the jump from the rural riverside landscape of the first half of the 20 century to the environmental degradation after the 1960s.

${ }^{4}$ The sample includes respondents from the life-cycle stages: young adulthood (15-29), adulthood (30-49), young old (5069) and old-old (70+) (Hay, 1998).
} 
physically use and/or act upon the material space, becoming their transitory "owners" during that spatially embedded practice (e.g. walking, growing plants, lying down to rest, cycling, etc.). The interviewees suggested a route for getting to know the river as a living space which, in most cases, included their own actions for transforming it. Meanwhile, the direct experience of the place on the walk provided a broader understanding of the river space for both the researcher and the interviewees. During the research process the anonymity of all the people interviewed was guaranteed.

\subsubsection{Pictures and maps}

Throughout the entire data collection process, it was considered important to take photographs in order to relate the inhabitants' explanations with the physical reality described and to assist with comprehension during the analysis of the data. The photographs taken by the researchers themselves, along with archive photographs collected beforehand and photos donated by the interviewees, were classified according to established spatial categories and cross-referenced on a single map. Thus, the analysis of the inhabitants' narrative was supported by geo-referenced photos, providing a continuous link to the territory being studied and a more detailed spatial visualization of the appropriation of the river (Verd \& Porcel, 2012).

\subsection{Analytic procedure}

The data was processed using the ATLAS.ti software. This allowed all the information to be handled in a centralized way and facilitated dynamic, integrated and rigorous data processing (Kelle, 1995; Ryan \& Bernard, 2000; Friese, 2012).

The result of the integration of qualitative data is summarized in Table 2, which shows its complementary function in meeting the objective of the study. 
TABLE 2

Integration of qualitative data from different sources

\begin{tabular}{|c|c|c|c|}
\hline Methods & Limitations & Potentialities & $\begin{array}{l}\text { Aspect that meets the objective } \\
\text { of the study }\end{array}$ \\
\hline $\begin{array}{l}\text { Participant } \\
\text { observation }\end{array}$ & $\begin{array}{l}\text { Limited oral } \\
\text { information. }\end{array}$ & $\begin{array}{l}\text { Allows a bridge between } \\
\text { narrative (understanding of } \\
\text { the place) and practice } \\
\text { (social behaviour). }\end{array}$ & $\begin{array}{l}\text { Categorization of the spatial } \\
\text { environment and types of } \\
\text { activities. }\end{array}$ \\
\hline $\begin{array}{l}\text { Documentary } \\
\text { research }\end{array}$ & $\begin{array}{l}\text { Potentially biased } \\
\text { pre-prepared } \\
\text { information. }\end{array}$ & $\begin{array}{l}\text { Provides historical } \\
\text { information. }\end{array}$ & $\begin{array}{l}\text { Knowledge of the evolution of the } \\
\text { relationship between the } \\
\text { inhabitants and the river. }\end{array}$ \\
\hline $\begin{array}{l}\text { In-depth } \\
\text { interviews }\end{array}$ & $\begin{array}{l}\text { Limited spatial } \\
\text { information. }\end{array}$ & $\begin{array}{l}\text { The personal experiences of } \\
\text { the interviewee enrich the } \\
\text { oral content. }\end{array}$ & $\begin{array}{l}\text { Knowledge of the cognitive, } \\
\text { emotional and behavioural links } \\
\text { between individuals and the river } \\
\text { environment. }\end{array}$ \\
\hline $\begin{array}{l}\text { Walking } \\
\text { interviews }\end{array}$ & $\begin{array}{l}\text { Limited available } \\
\text { information, being } \\
\text { more difficult to } \\
\text { gather as greater } \\
\text { involvement from the } \\
\text { interviewee is } \\
\text { required. }\end{array}$ & $\begin{array}{l}\text { Enriches the oral content by } \\
\text { means of speech-spatial } \\
\text { integration. }\end{array}$ & $\begin{array}{l}\text { Knowledge of the more territorial } \\
\text { aspect of people-place bonds. }\end{array}$ \\
\hline $\begin{array}{l}\text { Photographs } \\
\text { and maps }\end{array}$ & $\begin{array}{l}\text { Non-existent oral } \\
\text { information. }\end{array}$ & $\begin{array}{l}\text { Permits spatial } \\
\text { visualization. }\end{array}$ & $\begin{array}{l}\text { Supports the identification of a } \\
\text { link between the appropriation } \\
\text { process and the prevalent spatial } \\
\text { references. }\end{array}$ \\
\hline
\end{tabular}

Once the texts of the interviews had been entered and classified according to the control variables (age and number of years living in the municipality), and after a first review of the contents of the interviews, three 'Environmental Experience Groups' (EEG) were established; in other words, groups of individuals who, through their own interaction with the river, had similar views, feelings and relations towards it (Nogué, 1985, p.72). The first group (EEG 1) was made up of people engaged in individual pursuits but not regularly enough to be a structured routine; the second group (EEG 2) by people engaged in recurrent individual pursuits integrated into their daily lives; and the last group (EEG 3) by people 
engaged in a recurrent collective activity in self-organized local groups.

TABLE 3

Characterization of interviewees classified according to the EEG

\begin{tabular}{|c|c|c|c|c|c|c|c|c|c|c|c|c|c|c|c|}
\hline & \multirow[t]{2}{*}{ Inhab } & \multicolumn{4}{|c|}{ Age stage } & \multicolumn{3}{|c|}{ Length of residence } & \multicolumn{4}{|c|}{ Years of relation with the river } & \multicolumn{3}{|c|}{ Generation } \\
\hline & & $15-29$ & $30-49$ & $50-69$ & $70+$ & $<10$ & $10-25$ & $25+$ & $<5$ & $5-9$ & $10-24$ & $25+$ & $1 \mathrm{st}$ & 2nd & $3 \mathrm{rd}$ \\
\hline EEG*1 & 15 & 5 & 4 & 5 & 1 & - & $\begin{array}{c}4 \\
\text { 3born }\end{array}$ & $\begin{array}{c}11 \\
\text { 10born }\end{array}$ & 10 & 4 & 1 & - & - & 10 & 5 \\
\hline EEG 2 & 28 & 2 & 5 & 12 & 9 & $\begin{array}{c}1 \\
\text { Oborn }\end{array}$ & $\begin{array}{c}8 \\
\text { 2born }\end{array}$ & $\begin{array}{c}19 \\
\text { 12born }\end{array}$ & 3 & 11 & 5 & 9 & 13 & 13 & 2 \\
\hline EEG 3 & 14 & - & 8 & 5 & 1 & - & $\begin{array}{c}2 \\
\text { Oborn }\end{array}$ & $\begin{array}{c}12 \\
\text { 12born }\end{array}$ & - & 1 & 10 & 3 & 3 & 8 & 3 \\
\hline Total & 57 & 7 & 17 & 22 & 11 & 1 & $\begin{array}{r}14 \\
\text { 5born }\end{array}$ & $\begin{array}{c}42 \\
\text { 34born }\end{array}$ & 13 & 16 & 16 & 12 & 18 & 28 & 11 \\
\hline
\end{tabular}

*EEG (Environmental Experience Group)

" $n$ born" indicates the number of inhabitants who are born in the area over the total.

Afterwards, an iterative analysis was conducted following the techniques described by Miles and Huberman (1994): coding, definition of matrices based on the established codes, drawing of conclusions and verification. In the first phase, an open coding was used which inductively identified the categories of spaces and the types of activities (Alexander et al, 1977) carried out in the area around the river by means of descriptive codes arising from the data itself (e.g. peri-urban park, woodland, river, practice of sports, daily walks, etc.), all associated with a geo-referenced representative photo. The second coding phase identified perceptions and meanings of the riverside environment by means of interpretative codes in reference to more abstract concepts (e.g. negative or positive perceptions, aesthetic appreciation, memories of floods, etc.). During these initial coding phases, the ethnographic notes of participant observations were entered as memorandums which were linked with the corresponding quotes and codes. In the third phase, the coding process took on an explanatory role, seeking interrelations between the case study and the theoretical starting model (appropriation of the space via action-transformation and via symbolic 
identification). To do so, an internal triangulation was made between: the spatial dimension (where), the activities, meanings and perceptions (what), the time factor (when), and the environmental experience groups (who). At this point, the resulting codes served as master codes with an inferential and explanatory nature of the process of appropriation (e.g. aesthetic response, attachment, commitment). Finally, the interrelations identified between the established codes allowed the process of appropriation of the riverside environment to be modelled.

The following section presents the analysis of the empirical data and illustrates the resulting concepts and statements based on the quotes from the interviews translated from the original Catalan.

\section{ANALYSIS}

The application of the theoretical model of the appropriation of space proposed by Vidal and Pol (2005), with a particular emphasis on the time variable, allows for the identification of three phases in the process of appropriation of the riverside environment of the Caldes river: (1) aesthetic response, (2) place attachment and (3) commitment. These three phases are all interrelated and, though not necessarily in sequential form, give rise to an incremental process of appropriation that typically result in a sense of responsibility of the subject towards his/her environment. These three phases are described below, in accordance with: (a) the relationship established between the cognitive, affective and behavioural dimensions; (b) the dominant spaces of appropriation (DSA); and (c) the characteristic Environmental Experience Groups (EEG).

FIGURE 4

Conceptual model of spatial appropriation of Caldes river corridor 


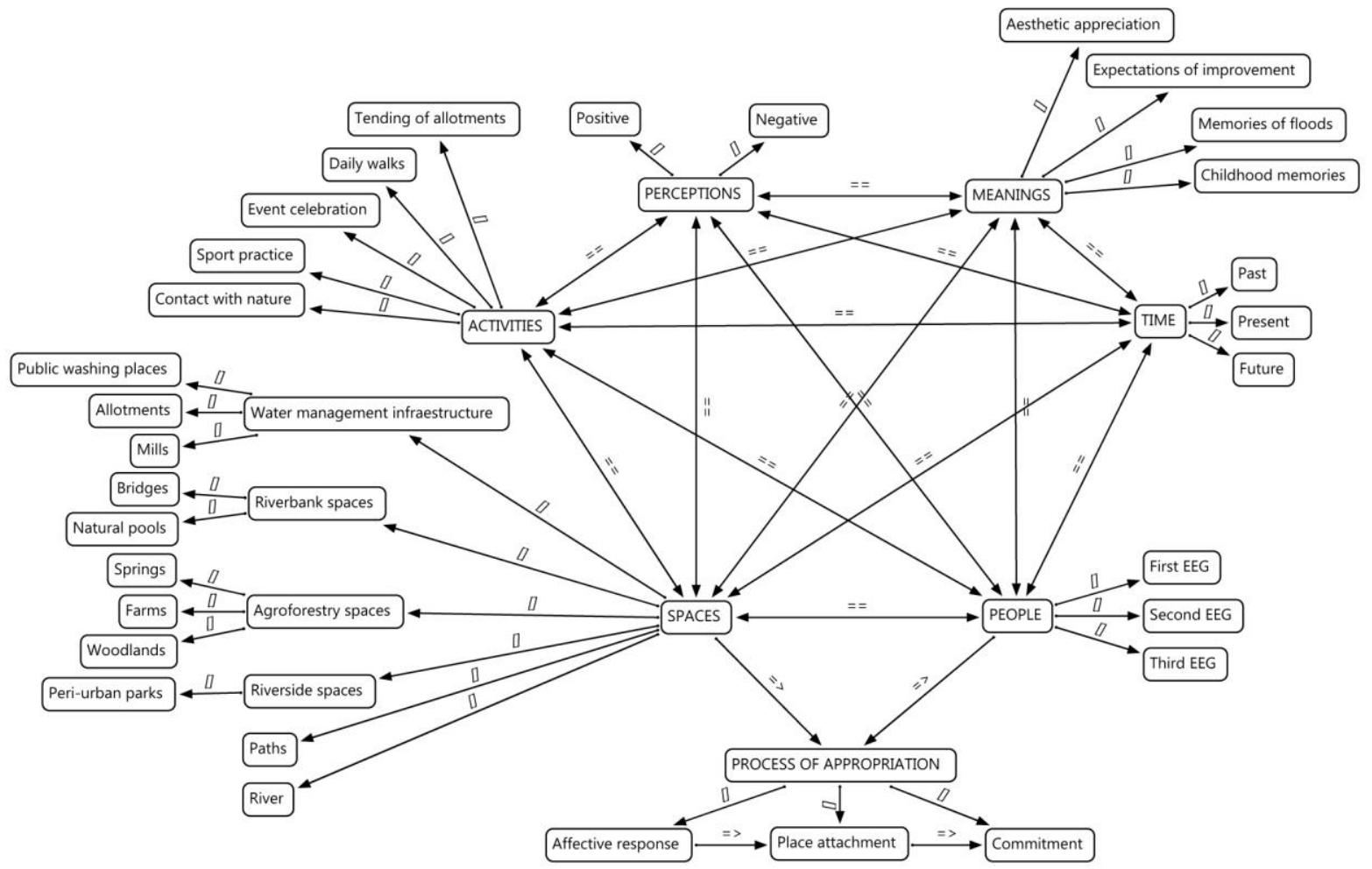

3.1. First phase: from spatial recognition to aesthetic response

\subsubsection{Relation between the cognitive, affective and behavioural dimensions}

In the first phase of the process of appropriation of the river, the prevalence of the cognitive dimension over the affective and behavioural dimensions can be observed. Knowledge of the riverside environment generates an aesthetic evaluation associated with its visual properties and the wellbeing they offer, although in certain cases this positive evaluation is subordinate to safety in view of the possible risk of flooding. In relation to the visual properties of the river which spark off an aesthetic response in people (Ulrich, 1983), the testimonials of the interviewees highlight: (1) the scenic complexity of the river, associated with its biodiversity and the dynamic nature of river landscapes; (2) the scenic depth of the natural surroundings which allows them to "broaden their views" and "breathe"; and (3) the feeling of security that comes from 
visiting the river due to feelings of visual control and protection from traffic and the risk of floods (see Table 4, [a]).

Over time, this positive evaluation triggers the user's identification with the riverside environment as a projection of their self and activates the desire for interaction. In this way, the initial aesthetic response impels a cognitive and affective evaluation of the place which reinforces the sense of belonging (see Ittelson, 1973; Ulrich, 1983; Hay, 1998). As a result, sporadic individual practice may evolve towards recurrent individual practice, with the consequent build-up of experiences associated with the river and the generation of more profound processes of personal bonding typical of the next phase.

\section{FIGURE 5}

Conceptual model of the first phase of the process of appropriation

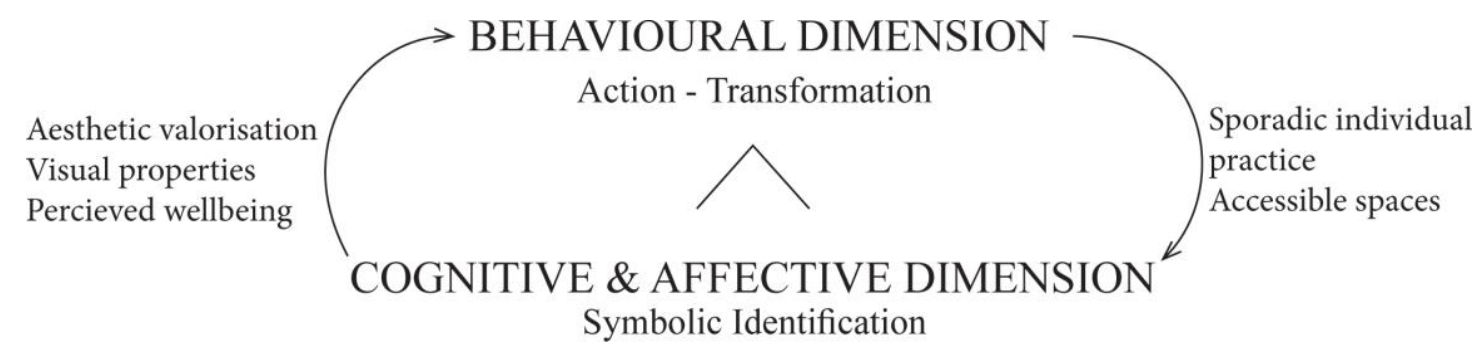

\subsubsection{Dominant Spaces of Appropriation}

Six categories of spaces which generated an aesthetic response were identified: (1) water management infrastructure, (2) riverbank spaces, (3) agroforestry spaces, (4) riverside spaces, (5) paths and (6) river (see Table 3). With regard to the geographical scale (Altman \& Low, 1992; Hidalgo \& Hernández, 2001), the first five address an individualized viewpoint of specific locations with very diverse characteristics, while category (6), river, refers to the vision of the river as a whole on a territorial scale. 
The water management infrastructures (1) and the riverbank spaces (2) have a very clear delimitation and the positive evaluation of these places derives from their physical characteristics and the possibilities of direct interaction that they offer (affordance - Gibson, 1979). The same applies to the network of paths (5), but in this case, based on accessibility and scenic quality, the continuity of the route is a determining factor in the user's aesthetic response, as it facilitates the connection of urban sectors with the area around the river and encourages its comprehension (see Table 4, [b]). On the other hand, the agroforestry spaces (3) and the riverside spaces (4) represent much larger geographical areas with more diffuse boundaries. In these cases, there is a large-scale evaluation of the space, often associated with the desire to preserve them in view of the threat of urban continuum. Finally, two types of general reference to the river space were detected (6): the river as a linear supra-municipal park offering leisure opportunities all along its course, and the river as a visual parenthesis between urban areas or a scenic backdrop (see Table 4, [c]).

Considering the answers as a whole, we can assert that the segmented spatial references are more numerous and alternate with general spatial references, but without establishing correlations between the two types. This fact may be related to the immediacy of the bond with the river typical of this phase, which lacks the richness of time that is required for its conceptualization as a prevalent spatial environment.

\subsubsection{Characteristic Environmental Experience Groups}

The three environmental experience groups are present in the first phase of the process of appropriation of the river space, but with some nuances, mainly with regard to the type of practices concerned and the length of the relationship with the river. The 
individuals in the first EEG who engaged in individual sporadic practices and had not yet assumed them as structured habits, primarily made reference to recently upgraded spaces, mainly riverside paths and parks, with which they had been related for less than 10 years (see table 3 ). In these cases, the aesthetic response of the individuals is associated with the stereotypes developed over recent years to promote the social use and environmental recovery of the river. This produced a positive evaluation of places in comparison with other spaces, but does not necessarily denote personal emotional bonds with the riverside environment (see table 4, [d]).

The interviewees in the second EEG (recurrent individual practice) and the third EEG (recurrent collective practice by local self-organized groups) demonstrate a much larger window of appreciated places, and include other significant spaces related to local history and personal experiences over many years.

TABLE 4 First phase of the process of appropriation. Literal extracts from the interviews

\footnotetext{
\begin{tabular}{clc} 
EEG $^{1}$ & Quote & DSA $^{2}$ \\
\hline 1 & "For a couple of years there's the Green Route and it allows people to go and see the stream. On Saturdays, & 5
\end{tabular} for example, I take my bicycle down there and you find that there are lots of people, it's very pleasant and obviously the ducks are a talking point. The riverside paths give you the opportunity to enjoy it all, it's difficult to think anything better, isn't it? The enjoyable feeling of walking alongside the river..." Male, aged 52 , born in the area, owns a local real estate agency.

1 "I like the area behind the church very much and also the allotments. And now there's the public washing places that have been very well restored, as well as the Roman baths, but everybody knows about them. I've always loved going round behind the church to admire the allotments!" Female, aged 26, born in the area, works as a freelance architect.

$1 \quad[d]$

"The truth is that I really like this area, now that I have the afternoons free, I find it one of the most beautiful places in Santa Perpètua. What I really like about the river is walking along the right bank, the esplanade and those saplings, the view. I don't know... I just like it. People are going to walk around the stream to enjoy what you might say is more of a park-like scenario." Female, aged 55, has lived in the area for 22 years, works in a pharmacy.

2 "Everything behind here was very cut off, a really run down and tough area where people used to smoke joints and shoot up... And now below here they are just finishing off the riverside pathway which is really great. Things have changed a lot since opening the path." Male, aged 30, born in the area, works in a bar.
} 
2 "These are family photos showing how beautiful the river can be... That's downstream of the campsite, in the area of Remei, where there are some really nice natural pools" Male, aged 49, born in the area, owns an ironmonger's shop.

2 [a]

"I like the river because a water course brings life to a community, especially when it is well managed environmentally... which then offers quality of life, even more so with the chance of being able to walk to places alongside the river now that there is no perceived danger of flooding; yes, above all it's to do with quality of life." Male, aged 58, has lived in the area for 28 years, works for a local newspaper.

$3 \quad[a]$

"People go to the river to escape from routine, for me it's like the door to the countryside at it allows people to breathe and broaden the view. Change the grey urban routine... "Female, aged 30, born in the area, architect and researcher at the university.

$2[\mathrm{~b}]$

"Something that was somehow overlooked two or three years ago, when channeling work was being done, they put forward a proposal to create a green zone and open up the pathways alongside the river. This has meant its use has grown. To some extent people are more familiar with the river. They may not yet appreciate it, but at least they are aware of it, they go there and they like it!" Male, aged 58, has lived in the area for 28 years, works for a local newspaper.

$2[\mathrm{c}]$

"Rivers are like a necessary natural break in the urban landscape and so this type of visual and physical parenthesis breathes life into the city, which I think is a good thing. In fact, what rivers and streams do is allow people to come into contact with nature. That's a very good thing." Male, aged 41, has lived in the area for 5 years, works as a freelance artist.

3 "What I like most are the small streams and the way they have attracted birds that we never dreamed of seeing there. It's nice and pleasant isn't it, especially being next to an industrial estate. It's sort of symbolic that wildlife and nature can live happily in a big park side by side with industry." Male, aged 70, born in the area, retired.

${ }^{7}$ EEG (Environmental Experience Group): (1) individual sporadic practice, (2) individual recurrent practice, (3) collective recurrent practice.

${ }^{2}$ DSA (Dominants Spaces of Appropriation): (1) water management infrastructure, (2) riverbank spaces, (3) agroforestry spaces, (4) riverside spaces, (5) paths and (6) river

\subsection{Second phase: from aesthetic response to place attachment}

\subsubsection{Relation between cognitive, affective and behavioural dimensions}

In the second phase of the process of appropriation, a balance can be observed between the behavioural, cognitive and affective dimensions typical of place attachment. This personal attachment is the result of interaction with the river over the years in terms of linearity (from past to present) and reiteration (recurrent everyday meanings and activities) (Altman \& Low, 1992; Milligan, 1998).

In the first case, memory plays an important role both for and against the appropriation of the river space, as memories cause a reconstruction of the experience in the 
emotional sphere which, over time, leads to a positive or negative 'distortion'. Specifically, a memory that propitiates attachment is expressed through two main channels (1) the idealized childhood memories as a form of symbolic attachment with the place transmitted from parent to child (Low, 1992, in Di Masso et al, 2008); and (2) the cultural representations of the history of the river as a source of admiration and pride for the inhabitants (see Table 5, [a] and [b]). On the other hand, memories associated with negative place experiences, such as periods of flooding and pollution, can complicate the attachment with the riverside environment, leading to negative or at least ambivalent attachments (see Table 5 [c], see also Fullilove, 1996; Manzo, 2005). The impact of these memories remains latent, and it is necessary for time to pass to overturn them and give way to a fresh relationship between the individual and the river space as a used and valued place. In these cases, weathering the difficulties and sharing hardships can help to build a stronger relationship with the river (see Table 5 [d]; see also Taylor \& Townsend, 1976; Hay, 1998).

With regard to the interaction with the river as a recurrent practice over time, four types of consolidated activities were observed which propitiate a greater sense of attachment with the river: environmental education workshops, exhibitions of art and local gastronomic products, leisure local events and meetings between different civic associations. These social and cultural events with their community spirit: (1) act as catalysts for the process of appropriation and give the river greater significance than just its spatial dimension; (2) incorporate an intangible component (symbolic or historic) which stems from the activities that have taken place there; and (3) facilitate the continuity of use of the place, having an active impact on the reconstruction of 
memory mentioned earlier (Gustafson, 2001; Lewicka 2005; Manzo, 2005) (see Table $5,[\mathrm{e}])$.

In short, in this second phase of the process of appropriation of the river, the accumulation over time of personal experiences allows the user to weave bonds with the place for aesthetic, functional and affective reasons in which the relationship between action-transformation and symbolic identification depends on the life-cycle stage (see Rowles, 1983; Hay, 1998). To be specific, amongst older people the effect of the symbolic identification seems to be greater than the action-transformation of the environment when it comes to explaining their attachment to the river, while amongst younger adults the two dimensions seem to be combined in a more balanced way.

In advanced stages of the process, the meaning of places is shared by other people and makes reference to symbolic spaces (Valera, 1993), developing the sense of place (Hay, 1998) and identification of the space as their own. This increase in affective bonds also facilitates the emergence of a feeling of familiarity and, leading immediately on from that, a feeling of safety and environmental control of the riverside area (Valera, 1996) which can lead to a local commitment to responsible management (Scannell \& Gifford, 2010b).

FIGURE 6

Conceptual model of the second phase of the process of appropriation

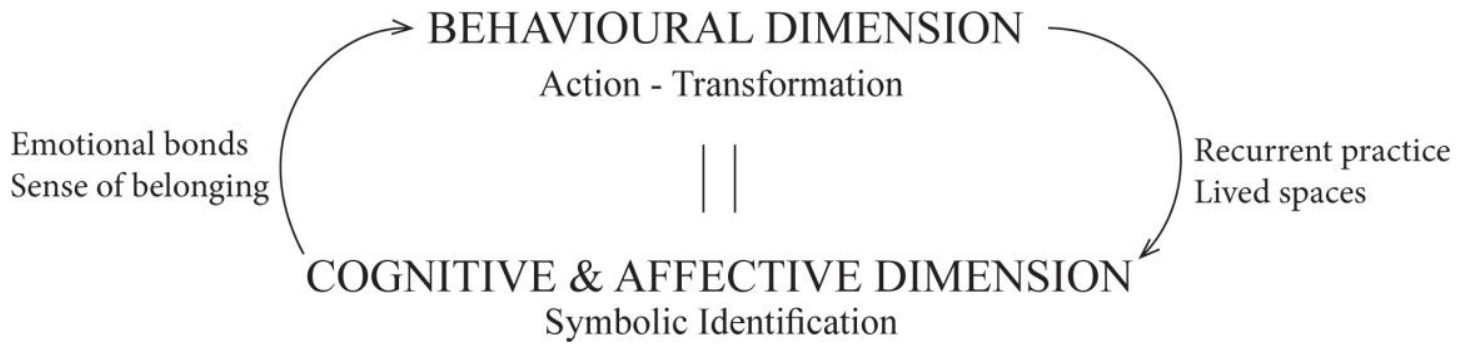

\subsubsection{Dominant spaces of appropriation}


Four categories of spaces that generate attachment have been identified: (1) water management infrastructure, (2) riverbank spaces, (3) agroforestry spaces and (4) riverside spaces (see Table 5). All these references respond to an individual vision of the spaces by the person concerned and, in relation to the prevalent environments of the previous phase, category (5), paths, is not mentioned perhaps because it is less favourable to emotional bonding. Despite this, the range of specific places in the other categories expands due to wider experiential knowledge over the years of the river as an everyday landscape. The general category of the river (6) is also excluded; yet, on the other hand, most of the individual places are recognized as part of a prevalent spatial whole.

With regard to category (1), the daily tending of allotments results in the personalization of the space (Villela Petit, 1976; Brower, 1980). In this case, however, this appropriation is restricted to the specific land under cultivation, and interviewees rarely expressed a sense of bonding with the riverside environment as a whole. In relation to riverbank activities (2), direct contact with the water has now vanished and the symbolic identification is recorded in childhood memories of learning to swim and going to the river to play and fish. Similarly, in relation to the agroforestry spaces (3), symbolic identification also predominates, represented by everyday practices, childhood memories, or a combination of the two. On this point, the impact of metropolitan dynamics is a determining factor. Thus the natural spaces of the municipalities further away from Barcelona serve as symbolic spaces (Valera, 1996) that have maintained their environmental and social value through to the present day and are regularly used for recreational activities. On the other hand, in the municipalities subject to a stronger influence from metropolitan dynamics, the 
settlement of numerous industrial areas has caused the significant degradation and even extinction of the agroforestry environment around the river and has led to the emotional disruption of people-place bonds. In these cases, people-place bonds cannot be strengthened by reiterated use and all that remains is a type of symbolic identification associated with remembered childhood spaces which no longer exist (see Table 5, [f]).

Finally, in relation to the peri-urban parks around the riverside (4) that have opened up to social and recreational use over the past decades, an emerging sense of attachment can be observed resulting from regular everyday use and an accumulation of satisfactory experiences (see Table 5, [g]).

Considering the responses as a whole, it can be asserted that there are prevalent spatial references which are assumed as everyday places for repeated use over time, associated with spatial areas on a larger geographical scale.

\subsubsection{Characteristic Environmental Experience Groups}

Only the second and third environmental experience groups formed part of the second phase of the process of appropriation of the riverside environment, centred on place attachment. The first EEG, with more recent relations with the river based primarily on sporadic practice, was removed from this phase, in which the affective attachment with the river is deeper and requires much more time and a more intensive relationship with the space itself (see Table 3). The second EEG, which engages in recurrent individual practice, consists of two subgroups depending on the number of years of relations with the river (see Table 3). In the first, young adults and adults attest bonds with the spaces that form part of their everyday practices in terms of the wellbeing they provide. In 
these cases, the meaning of the place arises from their own "experience-in-place" (Manzo, 2005). This is the case of the riverside areas for recreational use and contact with nature, established since late 1980s.

In the second group, made up of older adults and elderly people born in the locality, their bonds with the place are evident in their very detailed autobiographical memories (Rowles, 1983). For these long-term residents, experience of the place over many years has strengthened local knowledge, social networks and, at the same time, community bonds (Hay, 1998). In these cases, the subject specifies a solid attachment with the spaces that have been most significant in their lifetime. Finally, the third EEG, which engages in collective recurrent practice integrated in local self-organized groups, evidences an attachment with the riverside environment that is strengthened as and when these subjects get involved in its preservation and improvement (Uzzell, Pol \& Badenas, 2002).

In short, in this second phase most of the time factors that shape the place-bonds mentioned in the introduction can be observed. On the one hand, depending on the lifecycle stage the person has reached, their attachment to the river can be explained through action, identification or a balanced combination of the two. On the other, the length of time of the relationship with the space, individual and collective memory and intergenerational tales of bonding with the river serve as indicators of place attachment (see Table 5).

\section{TABLE 5}

Second phase of the process of appropriation. Literal extracts from the interviews 
"I arrived just before the installation of the water treatment plants. By then, people didn't go to walk along the river, it was seen as something ugly and unpleasant, and also, when there were floods, people were frightened. They wanted to cover the river to prevent floods. Now it has changed, especially since they opened this path along the river. It has changed quite a lot since people started coming and seeing the wildlife here. However, there are still a lot of people who would like to cover it, but things have changed a lot." Male, aged 48, has lived in the area for 21 years, owns his business.

\section{$2[\mathrm{~d}]$}

"In 1994 there was a very big flood which killed two people. So that triggered a very strong local demand in our neighbourhood to channel it. The people of Palau used to ignore the river, but because of the flood it became much more prominent, negatively, but prominent. Over time, it has been used more and more and people are aware now that we have a river that can be used, people can see that we have something of value." Male, aged 58, has lived in the area for 28 years, works for a local newspaper.

$2[\mathrm{e}]$

"This year they're holding the Festa Major concerts here again, by the river, and now they're also going to do the Revetlla party here. So young people like it and we have our memories of concerts here." Male, aged 24 , born in the area, student.

$2[\mathrm{f}]$

"Where the Vallès Integrated Goods Centre is now there used to be fields of vegetables and fruits. My parents had a house and fields there ... and I remember my grandfather liked to pick strawberries! You must know that there used to be some delicious produce there!" Female, aged 83, born in the area, retired.

2 "In the Hostal del Fum Park, the people from the railway association do activities, as do some other town's associations, for example the Cases d'Andalusia organizes events a couple of times a year, and then there are the Evangelist churches which come every year, probably for about 12 years now... I mean, there are a lot of associations, many from outside the town, that fell this park like their home" Female, aged 45, born in the area, works for the town council.

2 "Look, this is the mill whose ruins I showed you before on the picture, the one below the campsite. There used to be a very lovely natural pool here. I would say one of the most beloved and remembered natural pools by local people, we called the wide natural pool. It was one of the places with the most space for swimming." Male, aged 49, born in the area, owns an ironmonger's shop.

$2[\mathrm{a}]$

"The things I remember about the river are the natural pools. They all had a name. Below the Victoria Spa there was the patriots' pool, further up, past the Roman bridge, there was a very plain-looking pool which we called the fishermen's pool, further up there was the bucket pool, then the pulpit pool and then the wide pool. When we were child we used to swim there with our mates! I remember it well..." Male, aged 77, born in the area, farmer.

2 "I remember that me and my friends, when we were younger, and we never left town... that was when we were 12 or 13 years old, we used to come here for friends' birthdays to have a picnic. I've got loads of photos here... here we are with the blankets on the ground; all eating away... it was great! It's a place I love; it would have been a huge shame to have lost all that...” Female, aged 20, born in the area, student.

2 "The natural surroundings of the village, just by walking around frequently, you start recognizing them, feeling them as yours. That's what happened to me, not because I like it more or less but just because I go there such a lot... I go there often on my own and you end up loving it, it's that thing about contact generating affection.... isn't it? Male, aged 41, has lived in the area for 5 years, works as a freelance artist.

3 "Torre Marimon is really fantastic... both the building in itself and the surroundings. It's kind of... it's part of our culture because, after all, we have lived it. It's a really well-known spot and many people go there to have their wedding photos taken. Also for the people who come on their bikes from Santa Perpetua, this is the final point that they get to before turning round to go back." Male, aged 48, born in the area, owns a bicycle shop. 
"There are some spectacular landscapes here! Back in the 1920s or the 1930s, led by Manolo Hugué, there was a colony of very interesting local artists: Gispert, Planes Doria, Domingo, who really loved the river! They were excellent landscape artists and there are some wonderful paintings of the river." Male, aged 49, born in the area, owns an ironmonger's shop.

$3 \quad[\mathrm{~g}]$

"When you go often somewhere and really enjoy it, and you can take walks there with friends, with the kids playing... you really get the most out of the place and you also become more conscious of what's there, noticing the birds, and appreciating that it has a life... until you grow to love it." Male, aged 63, born in the area, works in a bank.

3 "Yes, this means everything to me, even though I've got my job and my home I come here everyday. My allotment is really important to me, and I think everyone feels the same about theirs. It's something you've got to like doing... but if you like it, it becomes your world." Female, aged 56, has lived in the area for 11 years, works in a hospital.

${ }^{7}$ EEG (Environmental Experience Group): (1) individual sporadic practice, (2) individual recurrent practice, (3) collective recurrent practice.

${ }^{2}$ DSA (Dominant Spaces of Appropriation): (1) water management infrastructure, (2) riverbank spaces, (3) agroforestry spaces, (4) riverside spaces, (5) paths and (6) river.

\subsection{Third phase: from place attachment to commitment}

\subsubsection{Relation between cognitive, affective and behavioural dimensions}

In the third phase of the process of appropriation, the behavioural dimension prevails over the cognitive and affective dimensions and gives rise to full personal commitment to preserving and improving the local environment which, in turn, propitiates the development of an environmental identity (Clayton, 2003). In this phase, attachment to the river achieves a broader time dimension to the point that past experiences are complemented by future expectations. This process can lead to more responsible proenvironment behaviour (Hines et al., 1987; Grob, 1995; Uzzell et al, 2002; Scannell \& Gifford, 2010a), especially for those who live near and care about the river. In particular, a notable consensus was observed with regard to the importance of cleaning the environment, recovering former paths and heritage elements and raising awareness about the environmental value of the river basin; however, contested opinions were revealed in relation to its re-naturalization (see Table 5, [a]). The recovery of riverside woodlands and the restoration of the riverbanks by removing certain channel walls are 
opposed by some people, mainly the elderly, who associate these actions with an increased risk of flooding. In this context, environmental education and personal motivation are key factors in activating the capacity of the individual to transform in favour of the common good, making the restoration of natural attributes compatible with the safety of the river space. In terms of education, while this in itself does not necessarily imply the development of pro-environmental behaviour, it certainly acts as a catalyst (Gifford, 2014, p.544). In a similar way, personal motivation plays a key role in place attachment, as it facilitates the successful achievement of personal goals (Kyle, Mowen \& Tarrant, 2004).

In this specific case study, three categories of solidarity actions were identified: (1) protection, (2) awareness-raising and (3) improvement of the riverside environment (see Table 6). Moreover, different degrees of commitment were observed; from a simple expression of pro-environmental beliefs to full pro-environmental participation, this being understood as people's direct involvement in the knowledge, assessment, prevention and correction of environmental problems (Castro, 1998).

\section{FIGURE 7}

Conceptual model of the third phase of the process of appropriation

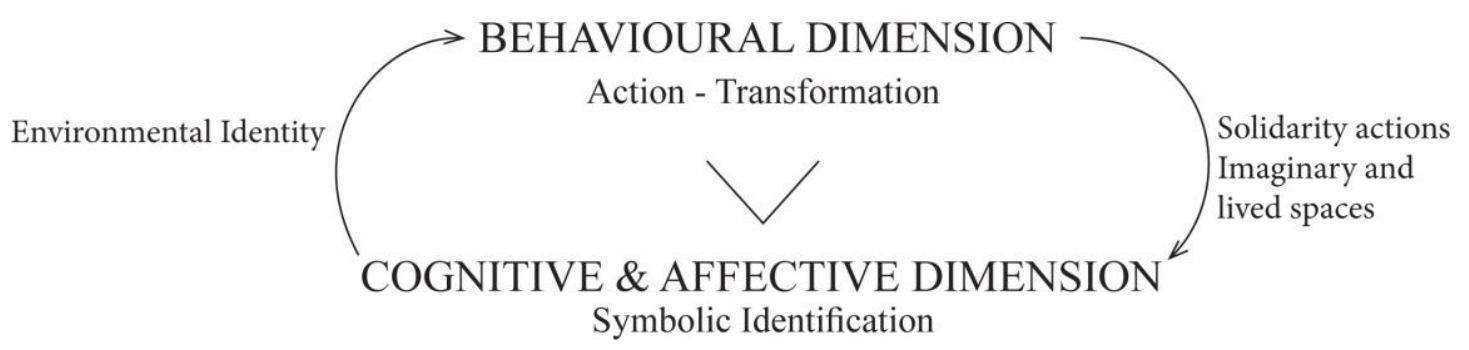

\subsubsection{Dominant Spaces of Appropriation}

Six different categories of spaces that generate personal commitment were identified: 
(1) water management infrastructure, (2) riverbank spaces, (3) agroforestry spaces, (4) riverside spaces, (5) paths and (6) river (see Table 6). In relation to the prevalent environments in the second phase, the categories of paths and the river as a whole are restored, with a particular emphasis on those spaces with greater environmental value and symbolic importance. In contrast to the first phase, in this phase the timescale factor of the experience allows more complex and integrated overall spatial representations to be constructed, according to the three types of solidarity actions: protection, awareness-raising and improvement.

Protective actions are promoted irrespective of whether they are individual or collective visions in relation to a threatened area. This is the case of those spaces that people want to protect against the risk of disappearance or anticipated change due to urban planning proposals (see Table 6, [b]). Awareness-raising actions, on the other hand, are promoted from the integrated understanding of the river stretch as a landscape unit; and common overall ideas related to its ecological and cultural values impel residents' involvement. For example, based on large-scale objectives such as environmental connectivity, the continuity of the network of paths, the water cycle and historical memory, specific actions are defined such as tree planting along the riverside, clearing the riverbanks, opening up paths, and recovering the natural pools and other heritage features.

\subsubsection{Characteristic Environmental Experience Groups}

Only the EEG that engages in recurrent collective practice in local self-organized groups can be found in the most advanced phase of the process of appropriation, associated with the full involvement of the subject. Even so, in the second EEG, the 
expression of personal wishes based on pro-environmental beliefs and knowledge denotes an incipient future commitment. In both cases, the individuals had lived in the municipality for more than 10 years (most of them were born there) and in the specific case of the people in the third EEG, they had more than 10 years of direct relations with the river space which coincided with the process of the physical and social recovery of the river (see Table 3 ).

In this phase, the EEG with recurrent collective practice adopted altruistic personal behaviour to the benefit of the community, contributing to developing sense of belonging towards the environment and towards the action group itself (Dono, Webb \& Richardson, 2010). To be specific, three types of local organizations and associations were identified in which the subjects of the third EEG engaged in their activity. The first of these were environment protection groups which either disbanded or dwindled once the conflict that originated them had been solved. The second were organizations dedicated to environmental education (see Table 6, [c]). In this case, the municipal affiliation of the groups is irrespective of their area of action, but the number of this type of association in a particular municipality reflects the local commitment to the environment and the environmental quality of the place itself. Finally, it is worth mentioning those groups or entities dedicated to improving the environment which facilitate an understanding of the riverside landscape in all its cultural and natural complexity. The success and continuity of these civic associations depends on a combination of time and three key factors: a wealth of natural and architectural heritage; the support of the local public administration; and citizen awareness.

In all cases, to a more or less direct extent, the impact of the time variable is evident in the display of solidarity actions. On the one hand, the generational factor and collective 
memory contribute to substantiating the desire to preserve the intrinsic character of the landscape against the threat of transformation. On the other hand, time and the intensity of the relationship with the river, as a group and for the common good, generate a feeling of self-satisfaction and social recognition (Castro, 1998) which compounds people-place bonds and the sense of belonging. Furthermore, in contrast to the previous phases, the time spectrum extends towards the future in the expression of pro-environmental expectations and beliefs with regard to the transformation of the river (see Table 6, [d]).

\section{TABLE 6}

\section{Third phase of the process of appropriation. Literal extracts from the interviews}

"For many years the Red Cross used to organize clearing sessions; every year a location would be chosen, and one year it was the river and so they put out an announcement to come and clear it. It was a Sunday, on a completely voluntary basis, and a whole gang of young people came along. People responded very well." Male, aged 51, born in the area, biologist and researcher at the university.

"There is a lack of education, because if you ask an older person what should be done about the river, they'll tell you it's full of rubbish and needs to be cleaned, that all the vegetation needs to be torn up, but that is just horrible, it's an aberration. The stream of Caldes needs riverside vegetation along the edges and the banks also need to be restored because a lot of earth has been lost, the terraces are not properly defined and on each level there should be a line of vegetation..." Male, aged 39, born in the area, works by an environmental agency.
} $\mathrm{SA}^{2} \quad \mathrm{DSA}^{3}$

3 "We do maintenance on the paths, both the short and medium-distance ones, and organize popular at the campsite.

"Some local groups, we insisted that the river had to be a significant element in the definition of the urban model of Caldes. That it couldn't be treated the way it had been in the past. The whole area on the other side of the river needed to be preserved from urbanisation, and of course what sparked off people's protests against the Urban Planning proposal (POUM) to urbanize it was the fact that the river might no longer be one of the boundaries of the municipality." Male, aged 49, has lived in the area for 28 , works for an environmental agency.

3 "Where the CIM is now they wanted to create a garden, but of course that would have been very expensive for the town hall so we proposed an allotment project so that the town wouldn't lose its tradition of irrigation-based agriculture and that was when they let us create these allotments, first those ones further up, but now it's really grown and there are around 200!" Male, aged 72, born in the area, retired. 
"We bring people closer to nature so they don't just see nature as entertainment, like going to a zoo, but as something more. We do excursions, activities, and walks... to really experience the nature. So obviously, the group of kids seeing that will experience something that will stay with them forever and will appreciate that the river needs to be cared for and maintained." Male, aged 50, born in the area, works for a local environmental organization.

3 "As a doctoral student, we proposed a line of action for the social and environmental rehabilitation of the allotments in collaboration with the Town Council. Since 2008 we've been holding an International Urban Art Exhibition to catalyse a new approach to and uses of water-related infrastructures." Female, aged 30, born in the area, architect and researcher at the university.

3 "The Discussion Group proposed certain environmental actions and one of those was recovering the natural pools along the river. But it all came to nothing because there wasn't enough impetus to get it underway. It's one of the things that I'm looking into again, on a personal level. A project that people would volunteer for, there's a lot of manual work involved..." Male, aged 49, has lived in the area for 28 , works for an environmental agency.

$3 \quad[d]$

"In 2012 we put forward the project "The Water Trails: research and action on self-management and community use. Instruments for change from the perspective of sustainability" with the aim of exploring this place's past, questioning the present and proposing models for the future." Female, aged 30, born in the area, architect and researcher at the university.

3 "Something needs doing, action is required. There was an initial preservation phase, to stop things getting worse, but now we have to take positive action. I think that if it were possible to focus the way in which public initiatives were organized so that the people would participate, it would surely be cheaper and would also give people a sense of personal involvement. We work on this direction. At grass roots level, we definitely want to keep it as natural as possible, because it really fills you with joy walking along certain sections of the Caldes river." Male, aged 63, born in the area, works in a bank.

${ }^{T}$ EEG (Environmental Experience Group): (1) individual sporadic practice, (2) individual recurrent practice, (3) collective recurrent practice.

${ }^{2} S A$ (Solidarity Action): (P) protection, (A-R) awareness-raising, (I) improvement.

${ }^{3}$ DSA (Dominant Spaces of Appropriation): (1) water management infrastructure, (2) riverbank spaces, (3) agroforestry spaces, (4) riverside spaces, (5) paths and (6) river.

\section{DISCUSSION}

It has been documented for this group that the appropriation of the riverside environment of the Caldes river in the metropolitan region of Barcelona takes place by means of long-term processes that include three phases: aesthetic response, place attachment and commitment. In the first phase, knowledge of the riverside environment leads to its regular use and its aesthetic evaluation. In the second phase, recurrent use and personal identification based on experiences and memories facilitates the development of emotional bonds with the river. In the third phase, attachment to the riverside environment, along with the consolidation of personal and collective pro-environmental beliefs, leads to the involvement of the person 
concerned in transforming and improving the river.

The breadth of the timescale during which people's cognitive experience in relation to the river develops is a determining factor in the constant process of appropriation and reappropriation. Of the three phases identified on which this case study is based, the time factor is significant in the more advanced phases. Thus place attachment and, eventually, personal commitment are strengthened over time, as the cognitive experience transcends the present to extend towards the past and the future and incorporates recurrent activities and meanings. Both reiteration in the use of the space, as well as time of residence in the broader area, seem to be temporal factors articulating the experience of spatial appropriation.

Also, narratives of place (e.g. Low, 1992), and mainly those inherited from earlier generations living in the same area, seem to be time-related social practices influencing how people experience their appropriation bonds. In this respect, we can argue that individual and collective memory shared with others can contribute to developing the affective bonds characteristic of the second phase of the process of appropriation, and at the same time catalyse the commitment of people living near the river to protect and improve the river space typical of the third phase. But the identification of the river through memory can also give rise to negative evaluations which hinder its appropriation. In both cases, the reconstruction of the past through memories involves a certain amount of 'distortion', whether positive or negative, not only individual but also shared and/or collective, which increases over time. This confirms the role of memory as an important factor in shaping the meaning of people-place bonds and the psychological nature of spatial uses (Chawla, 1992; Lewicka, 2008). 
Another expression of the influence of the time factor in the appropriation of space, according to the dual model (Pol, 2002; Vidal \& Pol, 2005), can be found in the changes in the people's life-cycles (different social commitments and implications at each stage of life), detecting different weighs for action-transformation or symbolic identification in each life-cycle stage. In the case under study, therefore, the elderly (old-old 70+) predominate in the symbolic identification of the riverside environment based on idealization (especially in the second phase), while among the other individuals interviewed, young adulthood (1529), adulthood (30-49) and young old (50-69), action-transformation is combined with symbolic identification, with variants depending on the phase of the process of appropriation (more symbolic identification in the first phase, balanced in the second phase, and more action-transformation in the third phase).

Beyond the time factor, the dual model of appropriation (Pol, 2002; Vidal \& Pol, 2005) considers that the experience of the place is independent of its intrinsic qualities and, rather, relates more to the intensity of the experience itself, the familiarity established with the place by means of its reiterative use, and the inherent social dimension that gives the place an entity and identity. Having said that, in the specific case of metropolitan river corridors, which were unused and somehow invisible environments a few decades ago due to their environmental degradation, the process of improving environmental quality and its impact on the physical and functional properties of the area are determining factors in the comprehension and use of that place. In this way, the functional dimension (which includes usability, accessibility, safety and environmental quality) is important in the first two phases of the process of appropriation, when the construction of meanings derives from: (1) the intrinsic qualities of the place, facilitating either continuity of use or, in contrast, its abandonment (as we have seen in the first phase) and (2) prolonged interaction over time, 
which makes it possible to deepen personal bonds with the place (as seen in the second phase). In contrast, the spatial determinants tend to lose their importance and can be superseded in those cases in which people's commitment strengthens along with the ecosocial value of the riverside environment (third phase).

Along with priority objective of examining the environmental-psychological conditions that shape the process of appropriation, this article has also enabled us to identify the consolidation, as the process itself advances, of three important aspects for the management of metropolitan river corridors: (1) people's commitment to improving the riverside environment and, in particular, responsible behaviour articulated through local selforganized groups; (2) recovery capacity in face of environmental traumas, especially the negative impact of flooding which is offset over time by the positive re-significance of the river and can even lead on to people becoming involved in improving the environment; and (3) the integration of individual and general ideas of the river corridor which, in stages of advanced appropriation, propitiates citizens' desire to engage in local improvement actions with global strategic meaning, particularly in the activist subgroup of the population.

\section{CONCLUSIONS}

This article has made an in-depth examination of the bonds that people develop towards metropolitan rivers through the dual model of appropriation of space as an explanatory mechanism. The re-introduction of this concept, which had fallen into certain disuse, has facilitated the use of significant analytical advantages such as the incorporation of the time factor and an emphasis on the dialectic and territorial nature of the processes of attachment. From this perspective, and with the support of a specific case study, we have analysed the relation between the cognitive, emotional and behavioural dimensions as well as the impact 
of modulating factors. The empirical evidence provided allows an argument in support of an integrative conceptual model (i.e. appropriation of space) which is less focused on place attachment, place identity and environmental preferences understood as neatly bounded psychological constructs hierarchically organized, but based more on preference, identification and affection as time-related modes of environmental experience framed by one same ongoing process of spatial appropriation.

\subsection{Main findings}

From the analysis of empirical data we can state the following conclusions and derive their practical implications. First, the time variable is crucial in the explanation of space appropriation processes and it is possible to conceptualize it more specifically by referring to life-cycle stages, inter-generational bonds, self-memories, family narratives of the past, cultural representations of the history of a place, and time spent in a space at different scales. Second, the spatial aspects are prevalent in the first phase of riverscapes apprehension (re-appropriation of previously unused environments), but need to be combined with individual and collective experiences of the place to articulate more mature and durable processes of space appropriation. In this respect, as the process of appropriation progresses, it increases citizens' operating capacity at a grassroots level to improve the everyday riverside environment. In this context, the organization of participative forms of management would be opportune to guarantee the maximum benefit from this capacity in order to promote current initiatives widely accepted by the community, such as cleaning the environment, restoring former paths and recovering heritage elements. 
These findings warrant special attention for their political dimension and concur in the need to review the governance of metropolitan river corridors. In this sense, the usual municipal approach to management, based on technical knowledge and institutional decisions that are alien to the general public, do not take proper advantage of cumulative citizen awareness in cases of advanced appropriation. On the other hand, participative management above and beyond administrative boundaries, based on experiential knowledge and geared towards citizen co-responsibility, could make better use of this consolidated sense of belonging and activate actions of the existing local groups in a more organized way.

\subsection{Limitations and future directions for research}

Some limitations to this study are worth considering below as a starting point for future research. First, one could reasonably argue that, since the empirical evidence provided in this article does not derive from a longitudinal study exploring the same subjects over time, but from different groups of people, we are not strictly demonstrating how people-place bonds develop over time across the same process of appropriation. While accepting this limitation, which is clearly related to the ethnographic approach of our case study, it is equally true that the groups were selected mostly on the basis of their length of residence by and relationship with the river, added to intensity of use and implication. This latter circumstance puts a particular emphasis on the time-hypothesis as a relevant one, considering each group as representing different moments of the same process of appropriation over time. The amount of retrospective discourse (i.e. narratives remembering the place in the past) in some groups and not in others can be also seen as an indicator of time shaping substantially different relationships with the river corridor, as well 

generational people-place relationships, and the reiteration of spatial uses.

Although personal variables other than time-in-place relationships could be the basis of such differences between groups expressing different types of bonds, the empirical data gathered does not support this argument more than the temporal one. In other words, even if this is not a longitudinal study that strictly demonstrates evolving bonds over time, the passing of time in the place (e.g. being born in the area, having lived there for less than 10 years or more than 25 years) is a significant variable when accounting for differences in the modes of experiencing and (re)appropriating the environment between groups (e.g. more aesthetic preference, more attachment-like bonds, or more environmental commitment). If time-passing-by is the main factor explaining the evolution of the same bond over time for the same group in one single process of appropriation, it is still, of course, a hypothesis to be tested in future research.

A second limitation relates to the fact that the selected sample does not include the minority collectives who use the area around the river and consequently the research offers a partial approximation of the process of appropriation, limited to the dominant users. This assertion suggests that it would be worthwhile undertaking a study of the negative appropriations associated with the current conflicts over the use of the river space.

Additionally, the paper focuses on a single case study (which impedes generalization) and on an individualized approach gathering the personal input of each individual, yet does not go into a detailed analysis of the collective forms of attachment to the environment. Even though cultural representations relating to the past of the river have been identified and group actions to improve the river space have been examined, an exploration of the social representations that structure the everyday experience of the people living around the river 
is yet to be undertaken.

Finally, the impact of sociocultural factors on the process of appropriation has not been given a great deal of consideration. Age, gender, residential status and the place of residence of each individual were only taken into account as complementary factors when selecting the interviewees with the aim of guaranteeing the internal diversity of the environmental experience groups. In this respect, an analysis of these aspects lends itself as a further line of research for exploration based on the research already conducted. 


\section{References}

Alexander, C., Ishikawa, S. \& Silverstein, M. (1977). A Pattern Language: Towns, Buildings, Construction. New York: Oxford University Press.

Altman, I. \& Low, S.M. (1992). Place attachment. New York: Plenum Press.

Barker, R. G., \& Wright, H. F. (1951). One boy's day. A specimen record of behavior. New York: Harper \& Brothers.

Benages-Albert, M. \& Vall-Casas, P. (2014). "Vers la recuperació dels corredors fluvials metropolitans. El cas de la conca del Besòs a la regió metropolitana de Barcelona".

Documents d'Anàlisi Geogràfica, 60 (1), 5-30.

Brewer, J. \& Hunter, A. (2006). Foundation of multimethod research: synthesizing styles. Thousand Oaks: Sage.

Brower, S.N. (1980). Territory in urban settings. In I. Altman, A. Rapoport \& J.F. Wohlwill (Eds.), Environment and Culture. Col. Human Behavior and Environment. (Vol. 4), pp. 179-207. New York: Plenum Press.

Brown, B.B. (1987). Territoriality. In D. Stokols \& I. Altman (Eds.), Handbook of Environmental Psychology, pp. 506-527. New York: Wiley.

Canyameres, E. (2004). Rieres, torrents, mines, molins i rescloses: l'aprofitament de les aigües a Santa Perpètua. Ajuntament de Santa Perpètua.

Castro, R. de (1998). Participación y voluntariado ambiental. Características y potencialidades. In R. de Castro, (Ed.), Voluntariado ambiental. Participación y conservación del medio ambiente, pp. 33-47. Sevilla: Consejería de Medio Ambiente.

Chawla, L. (1992). Childhood place attachments. In I. altman and S. Low (Eds.), Place attachment, pp. 63-86. New York: Plenum Press.

Clayton, S. (2003). Environmental identity: conceptual and operational definition. In S. Clayton, \& S. Opotow (Eds.), Identity and the natural environment: The psychological significance of nature, pp. 45-65. Cambridge, MA: MIT Press.

Creswell, J. (1998). Qualitative Inquiry and Research Design: Choosing among Five Traditions. Thousand Oaks: Sage

Creswell, J. (2007). Qualitative Inquiry and Research Desing: Choosing among Five Approches. Thousand Oaks (CA): Sage.

Di Masso, A., Vidal, T. \& Pol, E. (2008). La construcción desplazada de los vínculos persona lugar: una revisión teórica. Anuario de Psicología, vol. 39, 3, 371-385 
Di Masso, A., Dixon, J. \& Pol, E. (2011). On the contested nature of place: 'Figuera's Well', 'The Hole of Shame' and the ideological struggle over public space in Barcelona. Journal of Environmental Psychology, 31, 231-244.

Dono, J., Webb, J. \& Richardson, B. (2010). The relationship between environmental activism, pro-environmental behavior and social identity. Journal of Environmental Psychology, 30, 178-86.

European Council (2000a). EU Water Framework Directive 2000/60/CE, 23 October 2000.

European Council (2000b). European Landscape Convention, 1 March 2004.

Friese, S. (2012). Qualitative Data Analysis with ATLAS.ti. Thousand Oaks (CA): Sage.

Fullilove, M. (1996). Psychiatric implications of displacement: contributions from the psychology of place. Am J Psychiatry, 15, 1516-1523.

Generalitat de Catalunya (1987). Actuacions Industrials de l'Institut Català del Sòl.

Generalitat de Catalunya (1988). Actuacions Industrials de l'Institut Català del Sòl.

Generalitat de Catalunya (2010). Pla Territorial Metropolità de Barcelona (PTMB). Generalitat de Catalunya, núm. 5627, 12 de maig.

Gibson, J.J. (1979). The ecological approach to visual perception. Boston: Houghton Mifflin.

Gifford, R. (1987). Environmental psychology: Principles and practice. Newton, MA.: Allyn and Bacon.

Gifford, R. (2007). Environmental Psychology: Principles and Practice. Colville, WA: Optimal Books. 4th ed.

Gifford, R. (2014). Environmental Psychology matters. Annual Review of Psychology, 65, 541-579.

Giuliani, MV. (2003). Theory of attachment and place attachment. In M. Bonnes, T. Lee \& M Bonaiuto (Eds.), Psychological Theories for Environmental Issues, pp. 137-70.

Aldershot, UK: Ashgate.

Gordi, J. (Ed.) (2005). El paisatge fluvial a la conca del Besòs. Ahir, avui..., i demà? Barcelona: Consorci per a la Defensa de la Conca del Riu Besòs.

Graumann, C.F. (1976). The concept of appropriation (aneignung) and modes of appropriation of space. In P. Korosec-Serfaty (Ed.), Appropriation of space. Proceedings of the Strasbourg Conference. IAPC-3, pp. 113-125. Strasbourg, Lovaine La Neuve: CIACO. 
Grob, A. (1995). A structural model of environmental attitudes and behavior. Journal of Environmental Psychology, 12, 209-220.

Gustafson, P. (2001). Meanings of place: everyday experience and theoretical conceptualizations. Journal of Environmental Psychology, 21, 5-16.

Hammersley, M. \& Atkinson, P. (1994). Etnografía: métodos de investigación. Barcelona: Paidos. Retrieved from http://cataleg.uab.cat/record=b1284959 S1*cat

Harnik, P. (2000). Inside city parks. Washington, DC: Urban Land Institute and Trust for Public Land.

Hay, R. (1988). Toward a theory of sense of place. The Trumpeter, 6, 159-164.

Hay, R. (1998). Sense of place in developmental context. Journal of Environmental Psychology, 18, 5-29.

Hidalgo, M.C. (1998). Apego al lugar: ámbitos, dimensiones y estilos. Universidad de La Laguna. Unpublished $\mathrm{PhD}$ thesis.

Hidalgo, M.C. \& Hernández, B. (2001). Place attachment: conceptual and empirical questions. Journal of Environmental Psychology, 21, 273-81.

Hines, J.M., Hungerford, H.R. \& Tomera, A.N. (1986-87). Analysis and synthesis of research on responsible environmental behavior: a meta-analysis. Journal of Environmental Education, 18, 1-8.

Hyncer, R.H. (1985). Some guidelines for the phenomenological analysis of the interview data. Human Studies, 8, 279-303.

Ittelson, W.H. (1973). Environmental perception and contemporary perceptual theory. In W.H. Ittelson (Ed.), Environment and Cognition. New York: Seminar Press.

Jiménez, Y. (1997). Apropiación del espacio y conductas ecológicas responsables. Universidad Simon Bolivar. PhD thesis

Jones, P., Bunce, G., Evans, J., Gibbs, H., \& Ricketts Hein, J. (2008). Exploring space and place with walking interviews. Journal of Research Practice, 4(2), Article D2. Retrieved [7/03/2014], from http://jrp.icaap.org/index.php/jrp/article/view/150/161

Kaplan, R., Kaplan, S. \& Ryan, R.L. (1998). With people in mind: Design and management of everyday nature. Washington, DC: Island Press.

Kelle, U. (1995). Introduction: An Overview of Computer-Aided Methods in Qualitative Research. In U. Kelle (Ed.), Computer-Aided Qualitative Data Analysis: Theory, Methods and Practice, pp. 1-17. London: Sage. 
Korosec-Serfaty, P. (1976). Appropriation of space. Proceedings of the Strasbourg conference. IAPC-3. Strasbourg-Lovaine La Neuve: CIACO.

Korosec-Serfaty, P. (1984). The home from attic to cellar. Journal of Environmental Psychology, 4 (4), 303-321

Kyle, G., Graefe, A. \& Manning, R. (2005). Testing the dimensionality of place attachment in recreational settings. Environment and Behavior, 37, 153-177.

Kyle, G.T., Mowen, A.J. \& Tarrant, M. (2004). Linking place preferences with place meaning: an examination of the relationship between place motivation and place attachment. Journal of Environmental Psychology, 24, 439-54.

Lefebvre, H. (1974). La production de l'espace. Paris: Anthropos.

Lewicka, M. (2005). Ways to make people active: the role of place attachment, cultural capital, and neighborhood ties. Journal of Environmental Psychology, 25, 381-95.

Lewicka, M. (2008). Place attachment, place identity and place memory: Restoring the forgotten city past. Journal of Environmental Psychology, 28, 209-231.

Lynch, K. (1960). The Image of the City. Boston, Mass.: MIT Press,

Lynch, K. (1984). Reconsidering the Image of the City. In L. Rodwin et al. (Eds), Cities of the mind, pp. 151-161. New York: Springer.

Low, S.M. (1992). Symbolic ties that bind: Place attachment in the plaza. In I.Altman \& S.M. Low (Eds.), Place Attachment. Col. Human Behavior and Environment: Advances in Theory and Research. (Vol. 12), pp. 165-185. New York: Plenum Press.

Mc Harg, I. (1969). Design with nature. New York: Natural History Press, Garden City.

Manzo, L.C. (2005). For better or worse: exploring multiple dimensions of place meaning. Journal of Environmental Psychology, 25, 67-86.

Matthews, S., Detmiler, J. \& Burton, L. (2005). Geo-ethnography: Coupling Geographic Information Analysis Techniques with Ethnographic Methods in Urban Research.

Cartographica The International Journal for Geographic Information and Geovisualization, 40 (4), 75-90.

Milfont, T., \& Gouveia, V. (2006). Time perspective and values: An exploratory study of their relations to environmental attitudes. Journal of Environmental Psychology, 26, 72-82.

Miles, M.B. \& Huberman, A.M. (1994). Qualitative data analysis: and expanded sourcebook (2nd ed.). Thousand Oaks, CA: Sage.

Milligan, M. (1998). Interactional past and potential: The social construction of Place Attachment. Symbolic Interaction, 21, 1-33. 
Mitchell, D. (1995). The end of public space? People's park, definitions of the public, and democracy. Annals of the Association of American Geographers, 85, 108-133.

Nogué, J. (1985). Una lectura geogràfico-humanista del paisatge de la Garrotxa. Girona: Diputació de Girona / Col·legi Universitari de Girona.

Novotny, V., Ahern, J. \& Brown, P. (2010). Water Centric Sustainable Communities:

Planning, Retrofitting and Building the Next Urban Environment. New Jersey: John Wiley \& Sons, Inc. Hoboken.

Panareda, J. M. (2009). Evolución en la percepción del paisaje de ribera. Boletín de la $A G E, 51,305-324$.

Pinheiro, J. (2013). Time, a slippery challenge. Bulletin of people-environment studies, 39, 8-13.

Platt, R. H. (Ed.) (2006). The Humane Metropolies: People and Nature in the 21st-Century City. Boston: University of Massachusetts Amherst.

Pol, E. (1988). La psicología ambiental en Europa. Análisis sociohistórico. Barcelona: Anthropos.

Pol, E. (1996). La apropiación del espacio. In L. Iñiguez \& E. Pol (Ed.), Cognición, representación y apropiación del espacio. Col. Monografies Psico-Socio-Ambientals (Vol. 9), pp. 45-62. Barcelona: Publicacions de la Universitat de Barcelona.

Pol, E. (2002). El modelo dual de la apropiación del espacio. In R. Garcia Mira, J.M. Sabudedo Cameselle \& J. Romay Martínez (Eds.), Psicología y medio ambiente. Aspectos psicosociales, educativos y metodológicos. ( $1^{\text {st }}$ ed.), pp. 123-132. A Coruña: Publicaciones de la Universidad de A Coruña.

Pretty, G., Chipuer, H. \& Bramston, P. (2003). Sense of place amongst adolescents and adults in two rural Australian towns: The discriminating features of place attachment, sense of community and place dependence in relation to place identity. Journal of Environmental Psychology, 23, 273-287.

Proshansky, H.M. (1976). Appropriation and misappropriation of space. In P. KorosecSerfaty (Ed.), Appropriation of space. Proceedings of the Strasbourg Conference. IAPC-3, pp. 31-45. Strasbourg, Lovaine La Neuve: CIACO.

Proshansky, H.M. (1978). The city and the self-identity. Environment and Behavior, 10 (2), 147-169.

Proshansky, H.M., Fabian, A.K. \& Kaminoff, R. (1983). Place-Identity: Physical world socialization of the self. Journal of Environmental Psychology, 3, 57-83. 
Relph, E. (1976). Place and placelessness. London: Pion.

Rowles, G.D. (1983). Place and personal identity in old age: Observations from Appalachia. Journal of Environmental Psychology, 3, 299-313.

Rubinstein, R. \& Parlmelee, P. (1992). Attachment to place and the representation of the life course by the elderly. In I. Altman and S. Low (Eds.), Place attachment, pp. 139-161. New York: Plenum Press.

Ryan, R.L. (2000). A people-centered approach to designing and managing restoration projects: insights from understanding attachment to urban natural areas. In P.H. Gobster \& R.B. Hull (Eds.), Restoring nature: Perspectives from the social sciences and humanities, pp. 209-228. Washington, DC: Island Press.

Ryan, R.L. (2005). Exploring the effects of environmental experience on attachment to urban natural areas. Environment and Behavior, 37, 3-42.

Ryan, G. W. \& Bernard, H. R. (2000). Data Management and Analysis Methods. In N. K. Denzin \& Y.S. Lincoln (Eds.), Handbook of qualitative research. (2nd edition), pp. 769802. Thousand Oaks, California: Sage.

Scannell, L. \& Gifford, R. (2010a). Defining place attachment: a tripartite organizing framework. Journal of Environmental Psychology, 30, 1-10.

Scannell, L. \& Gifford, R. (2010b). The relations between natural and civic place attachment and pro-environmental behavior. Journal of Environmental Psychology. 30, 289-297.

Stanton, P. (Ed.) (2005). Rivertown: Rethinking urban rivers. Cambridge: The MIT Press.

Taylor, C. C. \& Townsend, A. R. (1976). The local sense of place as evidenced in northeast England. Urban Studies, 13, 133-146.

Torra, R., Farrero, A. \& Ténez, V. (2008). La recuperació dels paisatges fluvials metropolitans. El projecte de recuperació ambiental i paisatgística del riu Llobregat a la comarca del Baix Llobregat. Papers, 47, 44-53.

Ulrich, R.S. (1983). Aesthetic and affective response to natural environment. In I. Altman \& J.F. Wohlwill (Eds.), Behavior and the natural environment, pp.85-125. Nova York: Plenum.

Uzzell, D., Pol, E. \& Badenas, D. (2002). Place identification, social cohesion, and environmental sustainability. Environment and Behavior, 34, 26-53.

Valera, S. (1993). El simbolisme en la ciutat. Funcions de l'espai simbòlic urbà. Barcelona: Universitat de Barcelona. 
Valera, S. (1996). Psicología Ambiental: bases teóricas y epistemológicas. En L.Íñiguez \& E. Pol (Eds.), Cognición, representación y apropiación del espacio. Monografies PsicoSocio-Ambientals. (Vol. 9), pp. 1-14. Barcelona: Publicacions Universitat de Barcelona.

Verd, J. M. \& Porcel, S. (2012). An Application of Qualitative Geographic Information Systems (GIS) in the Field of Urban Sociology Using ATLAS . ti: Uses and Reflections. Forum Qualitative Sozialforschung/Forum: Qualitative Social Research, 13(2), Art. 14.

Vidal, T. (2002). El procés d'apropiació de l'entorn. Una proposta explicativa i la seva contrastació. Universitat de Barcelona. PhD Thesis available at: http://www.tdx.cesca.es

Vidal, T. \& Pol, E. (2005). La apropiación del espacio: una propuesta teórica para comprender la vinculación entre las personas y los lugares. Anuario de Psicología, 36, 281 297.

Villela Petit, M. (1976). Space as appropriated and appropriating. In P. Korosec-Serfaty (Ed.), Appropriation of space. Proceedings of the Strasbourg conference. 3rd IAPC, pp. 218-225. Lovain-la-Neuve: CIACO.

Warner, J., Van Buuren, A. \& Edelenbos, J. (Ed.) (2013). Making space for the river. Governance experiences with multifunctional river flood management in the US and Europe. London: IWA Publishing.

Werner, C., Altman, I. \& Oxley, D. (1985). Temporal aspects of homes. A transactional perspective. In I. Altman \& C. Werner (Eds.), Home environments, pp.1-32. New York: Plenum Press. 